\title{
85696 - AUTÓPSIA PSICOLÓGICA DE UM IDOSO SUICIDA: RELATO DE CASO
}

\section{Pôster - Geriatria}

\author{
Kauana Lindemann Wallauer / Wallauer, KL / ULBRA; Laura Rigo / Rigo, L / ULBRA; \\ Maureen Fernanda Ritter / Ritter, MF / ULBRA; Paulo Roberto Cardoso Consoni / Consoni, PRC / ULBRA
}

O suicídio, segundo a Organização Mundial da Saúde, é um problema de saúde pública, acometendo cerca de 800.000 indivíduos ao ano, sendo que a população idosa é a que mais comete o suicídio. A autópsia psicológica é um tipo de avaliação realizada para investigar retrospectivamente uma morte, visando compreender as razões e circunstâncias que levaram o idoso a tirar a própria vida. Neste estudo foi realizada uma entrevista qualitativa com um familiar, sobre um suicídio, por meio do Roteiro de Entrevista Semiestruturada para Autópsias Psicológicas e Psicossociais (RESAPP), que contém 44 perguntas simples e compostas, possuindo questionamentos específicos para esta faixa etária. $\mathrm{Na}$ velhice as características de personalidade tendem a se acentuar no idoso e, no caso da pessoa estudada, apresentou-se com transtorno de humor do tipo Bipolar e de personalidade com característica narcisista. Na família, após o ocorrido, é comum o surgimento de transtornos emocionais devido à perda e muitas vezes ao sentimento de culpa atrelada a impotência em mudar o fato. Na família em questão, a esposa desenvolveu transtorno depressivo e de ansiedade e a filha mais nova aflorou o transtorno de personalidade do tipo esquizofrenia paranoica e depressão. As doenças psiquiátricas que o idoso era portador, associadas com o desenvolvimento de agressividade, são consideradas fatores importantes de risco para o suicídio, principalmente quando as doenças em questão não são tratadas. A utilização de arma de fogo é considerada um dos meios mais comuns para prática do suicídio e o idoso em estudo cometeu o ato com a sua própria arma. Neste 6 estudo, a autópsia psicológica revelou a importância do tratamento das doenças psiquiátricas na velhice e que ignorar a ameaça de suicídio pode levar a tragédia que ocorreu na família deste. O suicídio pode ser evitado se for manejado e orientado da maneira correta. Por isso, é importante que sejam criadas ações de prevenção, alertando as pessoas idosas e seus familiares sobre fatores de risco e a necessidade de tratamento. 